\title{
Ochrona danych osobowych dotyczących zdrowia w świetle zmian wprowadzanych przez rozporządzenie 2016/679
}

\section{Streszczenie}

Od 25 maja 2018 roku zaczęło być stosowane rozporządzenie Parlamentu Europejskiego i Rady (UE) 2016/679 z 27 kwietnia 2016 roku w sprawie ochrony osób fizycznych w związku z przetwarzaniem danych osobowych i w sprawie swobodnego przepływu takich danych oraz uchylenia dyrektywy 95/46/WE (ogólne rozporządzenie o ochronie danych). Rozporządzenie wprowadza wiele zmian prawnych do przepisów o ochronie danych osobowych, w tym danych dotyczących zdrowia, które mają odpowiadać na postęp technologiczny i następujące zmiany społeczno-gospodarcze. Rozporządzenie wprowadza definicję danych o stanie zdrowia, nowelizuje przepisy dotyczące przesłanek uchylających zakaz przetwarzania szczególnych kategorii danych, do których zaliczają się dane dotyczące zdrowia, oraz zawiera szereg regulacji, np. w zakresie oceny skutków dla ochrony danych czy powołania inspektora ochrony danych osobowych, odnoszących się do tej kategorii danych osobowych.

Słowa kluczowe: dane dotyczące zdrowia, ochrona danych osobowych, RODO.

\section{Protection of Personal Data Concerning Health (As Changed by Regulation 2016/679)}

\section{Abstract}

From 25 May 2018, Regulation (EU) 2016/679 of the European Parliament and of the Council of 27 April 2016 on the protection of natural persons with regard to the processing of personal

1 Natalia Kalinowska - mgr, doktorantka na Wydziale Prawa i Administracji Uniwersytetu Kardynała Stefana Wyszyńskiego w Warszawie, prawnik w kancelarii Maruta Wachta, e-mail: nm.kalinowska@gmail.com. 
data and on the free movement of such data, and repealing Directive 95/46/EC (General Data Protection Regulation) will be applicable. The Regulation introduces many legal changes to the provisions on the protection of personal data, including data concerning health, which take into account technological progress and the following socio-economic changes. The Regulation introduces a definition of data concerning health, revises provisions regarding the grounds for repealing the ban on the processing of special categories of data which include data concerning health and contains a number of provisions (regarding these categories of personal data), e.g., in the area of data protection impact assessment or the appointment of a data protection officer.

Keywords: data concerning health, personal data protection, GDPR.

\section{Wstęp}

14 kwietnia 2016 roku Parlament Europejski przyjął rozporządzenie w sprawie ochrony osób fizycznych w związku z przetwarzaniem danych osobowych i w sprawie swobodnego przepływu takich danych (ogólne rozporządzenie o ochronie danych) ${ }^{2}$. Tym samym zakończyły się czteroletnie prace organów unijnych nad przygotowaniem powyższej regulacji. Rozporządzenie (zwane również RODO) zastąpi obowiązującą od 1995 roku dyrektywę 95/46/WE3 . Rozporządzenie kontynuuje podejście opierające się na podziale danych na dane osobowe zwykłe (choć nigdzie nie nazywa ich w ten sposób) oraz dane osobowe szczególnie chronione (zwane także wrażliwymi, sensytywnymi). Do szczególnych kategorii danych zaliczają się m.in. dane dotyczące zdrowia. Niniejszy artykuł stanowi analize zmian wprowadzanych przez rozporządzenie 2016/679 w kontekście danych dotyczących zdrowia. Wskazane zostaną podobieństwa i różnice w stosunku do obecnie obowiązującej ustawy ${ }^{4}$, przeanalizowana zostanie definicja danych dotyczących zdrowia oraz zmiana wymogów dotyczących zgody na przetwarzanie szczególnych kategorii danych z pisemnej na zgodę wyraźną, która będzie miała doniosłe znaczenie z perspektywy praktycznej.

2 Rozporządzenie Parlamentu Europejskiego i Rady (UE) 2016/679 z dnia 27 kwietnia 2016 roku w sprawie ochrony osób fizycznych w związku z przetwarzaniem danych osobowych i w sprawie swobodnego przepływu takich danych oraz uchylenia dyrektywy 95/46/WE (ogólne rozporządzenie o ochronie danych).

3 Dyrektywa 95/46/WE Parlamentu Europejskiego i Rady z dnia 24 października 1995 roku w sprawie ochrony osób fizycznych w zakresie przetwarzania danych osobowych i swobodnego przepływu tych danych.

4 Ustawa z dnia 29 sierpnia 1997 roku o ochronie danych osobowych. DzU z 1997 r., nr 133 poz. 883 . 


\section{Historyczne przyczyny uchwalenia rozporządzenia}

Ogólne rozporządzenie o ochronie danych weszło w życie 24 maja 2016 roku, a jego stosowanie wyznaczono na 25 maja 2018 roku. Ustawodawca europejski przewidział długi - dwuletni okres karencji, aby podmioty przetwarzające dane osobowe mogły lepiej przygotować się na nadchodzące zmiany. Opublikowany na stronie Rządowego Centrum Legislacji 14 września 2017 roku projekt ustaw o ochronie danych osobowych ${ }^{5}$, wraz z przepisami wprowadzającymi ustawę o ochronie danych osobowych ${ }^{6}$, przewiduje zmianę aż 133 ustaw. Opracowanie nowej ustawy było konieczne, ponieważ mimo iż dotychczasowa ustawa częściowo zawierała regulacje analogiczne do regulacji rozporządzenia, np. w zakresie definicji danych osobowych, to jednak byly w niej zawarte także przepisy uregulowane odmienne (choćby w zakresie definicji zgody osoby, której dane dotyczą) oraz regulacje, których w ogóle nie przewiduje rozporządzenie, np. w zakresie rejestracji zbiorów danych, natomiast regulacja unijna wprowadza nowe wymogi, np. obowiązek zgłaszania naruszeń, uregulowania dotyczące oceny skutków dla ochrony danych osobowych czy certyfikacji ${ }^{7}$.

Jeśli porówna się początki ochrony danych w Europie oraz standard, który wprowadza rozporząqzenie ogólne, widać wyraźnie ile wysiłku na przestrzeni lat włożono w to, aby poprzez wprowadzenie przepisów o ochronie danych osobowych zagwarantować należytą ochronę prawa do prywatności. Jest to szczególnie istotne w kontekście danych osobowych przetwarzanych w systemach informatycznych z dostępem do sieci publicznej.

Początki europejskiego prawa ochrony danych osobowych sięgają lat 70. XX wieku. To właśnie wtedy pojawiły się pierwsze (lokalne) ustawy o ochronie danych osobowych m.in. w Niemczech, Szwecji czy we Francji (por. Barta, Fajgielski, Markiewicz, 2015, s. 23). W 1981 roku uchwalono Konwencję 108 Rady Europy 8 - pierwszy akt prawny, który był i nadal pozostaje jedynym, prawnie wiążącym dokumentem o zasięgu międzynarodowym dotyczącym ochrony danych osobowych, którego celem było „zagwarantowanie [...] każdej osobie fizycznej [...] poszanowania jej praw i podstawowych wolności,

5 Projekt ustawy o ochronie danych osobowych, https://legislacja.rcl.gov.pl/docs//2/12302950/12 457664/12457665/dokument308361.pdf (dostęp: 22.11.2017).

6 Projekt ustawy - Przepisy wprowadzające ustawę o ochronie danych osobowych, https://legislacja.rcl.gov.pl/docs//2/12302951/12457706/12457707/dokument308373.pdf (dostęp: 22.11.2017).

7 Por. Uzasadnienie do projektu ustawy o ochronie danych osobowych, https://legislacja.rcl. gov.pl/docs//2/12302950/12457664/12457665/dokument308360.pdf (dostęp: 26.11.2017).

8 Konwencja nr 108 Rady Europy o ochronie osób w związku z automatycznym przetwarzaniem danych osobowych, sporządzona w Strasburgu dnia 28 stycznia 1981 roku. 
w szczególności prawa do prywatności, w związku z automatycznym przetwarzaniem jej danych osobowych". W następnych latach pojawiało się w Europie coraz więcej krajowych ustaw dotyczących ochrony danych osobowych. Ta wielość odmiennych, lokalnych regulacji zestawiona z pogłębiającą się integracją europejską oraz postępem technologicznym zintensyfikowała potrzebę ujednolicenia prawa ochrony danych osobowych w Unii Europejskiej i w 1995 roku uchwalono dyrektywę 95/46/WE ${ }^{9}$. W treści dyrektywy, w motywie 8 wskazano, że celem jej uchwalenia było zniesienia przeszkód w przepływie danych osobowych. Wskazano, że drogą do realizacji tego celu jest zrównanie stopnia ochrony praw i swobód jednostki w zakresie przetwarzania tych danych we wszystkich państwach członkowskich.

Od dłuższego czasu dostrzegano również potrzebę rewizji przepisów dyrektywy 95/46/WE ${ }^{10}$. Twórcy dyrektywy, tworząc ją w latach $90 \mathrm{XX}$ wieku, nie mogli przewidzieć wielu istotnych dla ochrony danych osobowych wydarzeń - przemian społeczno-gospodarczych (np. globalizacji) oraz tak szybkiego rozwoju nowych technologii, które miały wpływ na nowe sposoby przetwarzania danych osobowych. Dlatego regulacja uchwalona ponad 20 lat temu nie przystawała do obecnych czasów i nie zapewniała już wystarczającej ochrony ani w zakresie praw osób, których dane dotyczą, ani sposobów zabezpieczenia dostępu do danych ${ }^{11}$. Ponadto, dyrektywa była aktem obowiązującym pośrednio, wymagającym implementacji. Tworzyła tylko pewne ramy i standardy. W następstwie tego, w krajach członkowskich przepisy odnoszące się do ochrony danych osobowych nadal są w pewnym stopniu zróżnicowane, co utrudnia funkcjonowanie na rynku przedsiębiorcom, którzy w ramach swojej działalności przetwarzają dane osobowe w wielu krajach członkowskich.

Rozporządzenie to akt prawny bezpośrednio obowiązujący, dlatego będzie miał bezpośrednie zastosowanie we wszystkim państwach członkowskich Unii Europejskiej. Cele rozporządzenia są zbieżne z celami dyrektywy - przede wszystkim jest to zapewnienie w całej Unii spójnego i jednolitego poziomu ochrony danych osób fizycznych, tak aby umożliwić swobodny przepływ danych

9 Dyrektywa 95/46/WE Parlamentu Europejskiego i Rady z dnia 24 października 1995 roku w sprawie ochrony osób fizycznych w zakresie przetwarzania danych osobowych oraz swobodnego przepływu tych danych (Dz.Urz. WE L 281 z 23.11.1995 r.).

10 Już w 2010 roku wydano komunikat Komisji do Parlamentu Europejskiego, Rady, Europejskiego Komitetu Ekonomiczno-Społecznego oraz Komitetu Regionów „Całościowe podejście do kwestii ochrony danych osobowych w Unii Europejskiej".

11 Por. motywy 9 i 10, Rozporządzenie Parlamentu Europejskiego i Rady (UE) 2016/679 z dnia 27 kwietnia 2016 roku w sprawie ochrony osób fizycznych w związku z przetwarzaniem danych osobowych i w sprawie swobodnego przepływu takich danych oraz uchylenia dyrektywy 95/46/WE. 
osobowych w Unii Europejskiej oraz ułatwić funkcjonowanie przedsiębiorstw na jednolitym rynku.

W konsekwencji wszystkie państwa członkowskie UE będą stosowały przepisy wyżej wymienionego rozporządzenia ${ }^{12}$. $Z$ uwagi jednak na odmienności porządków i tradycji prawnych państw członkowskich rozporządzenie dopuszcza doprecyzowanie pewnych kwestii w prawie krajowym.

Znaczącą różnicą, którą wprowadza rozporządzenie, jest podejście oparte na ryzyku. Ryzyko (często stopniowane) naruszenia praw i wolności osób, których dane dotyczą, na gruncie rozporządzenia 2016/679, staje się jednym z kluczowych pojęć. Administrator oraz w różnym zakresie podmiot przetwarzający muszą brać pod uwagę istniejące i potencjalne ryzyka dla ochrony danych osobowych, by zastosować odpowiednie do nich rozwiązania. Takie podejście umożliwia skoncentrowanie się na sytuacjach najwyższego ryzyka, przy jednoczesnym zachowaniu odpowiedniego poziomu ochrony, gdy to ryzyko jest niskie i nie wymaga wykorzystywania całego instrumentarium środków przewidzianych przez ogólne rozporządzenie (Bielak-Jomaa, Lubasz, 2018, s. 341). Takie proaktywne podejście do ochrony danych osobowych odchodzi od znanego z ustawy podejścia opartego na drobiazgowej regulacji zabezpieczenia danych często odstającej od zakresu, kontekstu czy celów ich przetwarzania, nie gwarantując właściwego stopnia ochrony.

\section{Dane osobowe dotyczące zdrowia na gruncie dyrektywy i ustawy}

Zgodnie z definicją zawartą w art. 2 pkt a) dyrektywy, dane osobowe to wszelkie informacje dotyczące zidentyfikowanej lub możliwej do zidentyfikowania osoby fizycznej („osoby, której dane dotyczą”); osoba możliwa do zidentyfikowania to osoba, której tożsamość można ustalić bezpośrednio lub pośrednio, szczególnie przez powołanie się na numer identyfikacyjny lub jeden bądź kilka szczególnych czynników określających jej fizyczną, fizjologiczną, umysłową, ekonomiczną, kulturową lub społeczną tożsamość.

Definicja zawarta w art. 6 ustawy stanowi natomiast, że: „za dane osobowe uważa się wszelkie informacje dotyczące zidentyfikowanej lub możliwej do zidentyfikowania osoby fizycznej [...] Osobą możliwą do zidentyfikowania jest osoba, której tożsamość można określić bezpośrednio lub pośrednio, w szczególności przez powołanie się na numer identyfikacyjny albo jeden lub kilka specyficznych czynników określających jej cechy fizyczne, fizjologiczne, umy-

12 Ocena skutków regulacji - Projekt ustawy o ochronie danych osobowych, s. 3, https://legislacja. rcl.gov.pl/docs//2/12302950/12457664/12457665/dokument308359.pdf (dostęp: 24.11.2017). 
słowe, ekonomiczne, kulturowe lub społeczne. [...] Informacji nie uważa się za umożliwiającą określenie tożsamości osoby, jeżeli wymagałoby to nadmiernych kosztów, czasu lub działań”.

Obie definicje nieznacznie się od siebie różnią, ale różnice te nie wpływają, co do zasady, na zakres znaczeniowy tego pojęcia.

Definicja danych osobowych w polskiej ustawie, w jej pierwotnym kształcie brzmiała inaczej, uznając za dane osobowe „każdą informację dotyczącą osoby fizycznej, pozwalającą na określenie tożsamości tej osoby”. Taka redakcja przepisu spotkała się z krytyką nauki prawa - zarzucano, że była niezgodna z dyrektywą 95/46/WE, jako że za dane osobowe uznawała wyłącznie tzw. dane identyfikacyjne (por. Sibiga, 2003, s. 32; Barta, Litwiński, 2015, s. 75). Takie stanowisko zostało jednak słusznie poddane krytyce w nauce prawa, jako że za dane osobowe powinny zostać uznane wszelkie informacje, ,jeżeli tylko możliwe jest ich odniesienie do konkretnej osoby" (por. Barta, Fajgielski, Markiewicz, 2015, s. 383-384; Barta, Litwiński, 2015, s. 75).

Szczególnym typem danych osobowych są tzw. dane osobowe wrażliwe, sensytywne. Ustawa wskazuje, że zaliczane są do nich „dane ujawniające: pochodzenie rasowe lub etniczne, poglądy polityczne, przekonania religijne lub filozoficzne, przynależność wyznaniową, partyjną lub związkową, jak również dane o stanie zdrowia, kodzie genetycznym, nałogach lub życiu seksualnym oraz dane dotyczące skazań, orzeczeń o ukaraniu i mandatów karnych, a także innych orzeczeń wydanych w postępowaniu sądowym lub administracyjnym”. Przepis polskiej ustawy wykracza poza zakres pojęcia danych sensytywnych ukształtowany w dyrektywie 95/46/WE, obejmując szczególną ochroną również informacje o kodzie genetycznym i nałogach (por. Kulesza, 2000, nr 5; Barta, Litwiński, 2015, s. 308). Przetwarzanie tych danych jest co do zasady zakazane, jednakże istnieje wiele wyjątków od tego zakazu ujętych w art. 27 ust. 2 ustawy.

Katalog danych szczególnie chronionych „ma charakter taksatywny, dlatego nie istnieje możliwość poszerzenia go o dalsze kategorie danych, nawet gdyby wydawało się to uzasadnione, jak choćby w przypadku danych dotyczących adopcji. Nie zmienia to faktu, że w niektórych przypadkach mogą powstawać niejasności, czy dana informacja, którą da się powiązać z określoną osobą, ujawnia np. jej przekonania religijne lub polityczne bądź pozwala zorientować się o pochodzeniu rasowym lub etnicznym" (Barta, Fajgielski, Markiewicz, 2015, s. 486).

Nie ma wątpliwości, iż specyfika danych wrażliwych jako odnoszących się do sfery prywatności czy nawet intymności człowieka sprawia, iż konieczne jest zastosowanie szczególnych standardów ochrony w procesach przetwarzania tych informacji (Bielak-Jomaa, Lubasz, 2018, s. 278). 
Wskazuje się także, że dane wrażliwe, w przeciwieństwie do pozostałych, wiążą się ze znacznie większym poczuciem zagrożenia oraz niebezpieczeństwem wywołania na różnych polach (zatrudnienie, ubezpieczenie, kredytowanie itd.) decyzji dyskryminacyjnych.

W doktrynie podnosi się jednak, że nie zawsze jest jasne, czy dany rodzaj informacji powinien być zaliczany do danych szczególnie wrażliwych -mogą się pojawiać wątpliwości, czy pewne wiadomości (np. o tym, że ktoś używa okularów) powinny być poddane wzmożonej ochronie jako dane wrażliwe. Podobnie można się odnieść do informacji, że określona osoba pali fajkę lub papierosy, choć mamy tu do czynienia z nałogiem (Barta, Fajgielski, Markiewicz, 2015, s. 487).

Ani w dyrektywie, ani w polskiej ustawie nie znalazła się definicja danych dotyczących zdrowia, mimo że oba akty prawne odwołują się do tej kategorii. Ponadto, do tej pory w polskiej ustawie o ochronie danych osobowych i dyrektywie 95/46/WE (zarówno w polskiej, jak i w angielskiej wersji językowej) używano nawet różnych terminów na jej określenie - w polskich przepisach posługiwano się pojęciem „dane o stanie zdrowia”, a w dyrektywie „dane dotyczące zdrowia".

Próbując odpowiedzieć na pytanie o zależności między tymi pojęciami, warto odnieść się do rekomendacji R(97)5 Komitetu Ministrów do Państw Członkowskich dotyczącej ochrony danych medycznych ${ }^{13}$, w której te terminy funkcjonowały niejako zamiennie. Ponadto, rekomendacja $\mathrm{R}(97) 5$ nie tylko zrównywała znaczenie pojęć „dane o stanie zdrowia” i „dane dotyczące zdrowia”, ale stawiała je na równi z „danymi medycznymi” 14 . Potwierdzenie takiego podejścia można znaleźć również w polskiej doktrynie - podkreśla się, że mimo, iż relacja „danych dotyczących zdrowia” i „danych medycznych” nie jest jasna, to w praktyce te pojęcia mogą się zacierać (por. Wąsik, 2015).

W polskiej literaturze naukowej, próbując definiować pojęcie „dane o stanie zdrowia" wskazywano, na trudność interpretacyjną w tym zakresie. Paweł

13 Recommendation No R (97) 5 of the Committee of Ministers to Member States on the protection of medical data (Adopted by the Committee of Ministers on 13 February 1997 at the 584th meeting of the Ministers' Deputies), https:/www.google.pl/url?sa=t\&rct=j\&q $=\&$ esrc $=$ s\&source $=$ web $\& c d=1 \& \mathrm{cad}=$ rja $\&$ uact $=8 \&$ ved $=0$ ahUKEwjq5oOO0eHXAhWJIOw KHRqnDaMQFggqMAA\&url=https $\% 3 \mathrm{~A} \% 2 \mathrm{~F} \% 2 \mathrm{Frm}$. coe.int $\% 2 \mathrm{FCoERMPublicCommonSe}$ archServices\%2FDisplayDCTMContent\%3FdocumentId\%3D09000016806af967\&usg =AOvV aw2acyV-MKt3tPhMKpE7yAMD (dostęp: 26.11.2017).

14 Nie tylko zamiennie się ich używa - dane osobowe medyczne (w tytule), dane dotyczące zdrowia lub dane o stanie zdrowia (w treści); ale w definicji danych dotyczących zdrowia to pojęcie w wersji angielskiej jest tłumaczone jako medical data. 
Barta i Paweł Litwiński wprost wskazują, że z jednej strony informacja o tym, że komuś nic nie dolega, może być potraktowana jako informacja o stanie zdrowia (np. w przypadku oceny stanu zdrowia w trakcie badań nad jakimś produktem leczniczym), z drugiej zaś strony informacja o częstotliwości odwiedzin u swojego lekarza pierwszego kontaktu nie musi bezpośrednio odnosić się do stanu zdrowia osoby (osoba może po prostu czuć potrzebę częstych wizyt u lekarza, mimo że jej nic nie dolega) (Barta, Litwiński, 2015, s. 309). Niemniej jednak zgodnie $\mathrm{z}$ art. 27 ust. 2 pkt 7, dopuszczalne jest przetwarzanie danych wrażliwych (w tym danych o stanie zdrowia), jeśli te dane są ,przetwarzane w celu ochrony stanu zdrowia, świadczenia usług medycznych lub leczenia pacjentów przez osoby trudniące się zawodowo leczeniem lub świadczeniem innych usług medycznych, zarządzania udzielaniem usług medycznych i są stworzone pełne gwarancje ochrony danych osobowych".

Jak zauważają Janusz Barta, Paweł Fajgielski i Ryszard Markiewicz przez pojęcie ochrony stanu zdrowia, leczenia i świadczenia usług medycznych należy rozumieć także działania profilaktyczne, diagnostyczne, rehabilitacyjne (w tym kuracyjne); zatem jest dopuszczalne przetwarzanie danych o stanie zdrowia pacjenta również przez te podmioty medyczne, które uczestniczą w kierowaniu pacjenta na leczenie uzdrowiskowe. Natomiast osoby trudniące się zawodowo leczeniem lub świadczeniem innych usług medycznych to „personel medyczny", który tworzą - jak uważamy - nie tylko sami lekarze, ale również personel pomocniczy: pielęgniarki i laboranci oraz rehabilitanci (Barta, Fajgielski, Markiewicz, 2015, s. 498).

Niewątpliwie do kategorii danych o stanie zdrowia należy zaliczyć dane z dokumentacji medycznej. Wskazuje się także, że sama informacja o prowadzeniu dokumentacji medycznej dla określonej osoby może być uznana za dane o stanie jej zdrowia. Podobne stanowisko zostało wyrażone przez Grupę Roboczą ds. Ochrony Danych (Grupa Robocza) ${ }^{15}$ - wszelkie dane zawarte w dokumentacji medycznej należy traktować jako dane szczególnie chronione, które podlegają nie tylko ogólnym zasadom dotyczącym ochrony danych osobowych określonym $\mathrm{w}$ dyrektywie, lecz także szczególnym zasadom dotyczącym ochrony danych osobowych, mającym zastosowanie do przetwarzania informacji szczególnie chronionych. Generalnie wszelkie dane zawarte w dokumentacji medycznej należy traktować jako dane osobowe szczególnie chronione. Treścią dokumentacji medycznej są zatem dane osobowe, i to dotyczące najwrażliw-

15 Grupa Robocza została powołana na mocy art. 29 dyrektywy 95/46/WE. Jest ona niezależnym europejskim organem doradczym w zakresie ochrony danych i prywatności. 
szych sfer prywatności każdego człowieka. Obok danych o stanie zdrowia mogą to być dane genetyczne, dane o seksualności, dane o nałogach, a nawet dane określające przekonania religijne czy przynależność wyznaniową, np. gdy określony pacjent $\mathrm{z}$ uwagi na przekonania odmawia zgody na wykonanie określonego zabiegu (Krasińska, 2016).

Prowadzenie dokumentacji medycznej stanowi jeden z obowiązków podmiotów udzielających świadczeń zdrowotnych i zgodnie z ustawą o prawach pacjenta i Rzeczniku Praw Pacjenta ${ }^{16}$, dane osobowe pacjenta zawarte w dokumentacji medycznej podlegają ochronie określonej w tej ustawie oraz w przepisach odrębnych (m.in. ustawie o ochronie danych osobowych).

Zgodnie z art. 25 ustawy dokumentacja medyczna zawiera co najmniej:

1) oznaczenie pacjenta, pozwalające na ustalenie jego tożsamości:

a. nazwisko i imię (imiona),

b. datę urodzenia,

c. oznaczenie płci,

d. adres miejsca zamieszkania,

e. numer PESEL, jeżeli został nadany, w przypadku noworodka - numer PESEL matki, a w przypadku osób, które nie mają nadanego numeru PESEL - rodzaj i numer dokumentu potwierdzającego tożsamość,

f. w przypadku gdy pacjentem jest osoba małoletnia, całkowicie ubezwłasnowolniona lub niezdolna do świadomego wyrażenia zgody - nazwisko i imię (imiona) przedstawiciela ustawowego oraz adres jego miejsca zamieszkania;

2) oznaczenie podmiotu udzielającego świadczeń zdrowotnych ze wskazaniem komórki organizacyjnej, w której udzielono świadczeń zdrowotnych;

3) opis stanu zdrowia pacjenta lub udzielonych mu świadczeń zdrowotnych;

4) datę sporządzenia.

Przepisy ustawy wskazują ponadto, że w dokumentacji medycznej zamieszcza się także informację o wydaniu opinii albo orzeczenia wydanego przez lekarza.

Inną ustawą odnoszącą się do danych dotyczących zdrowia jest ustawa o systemie informacji w ochronie zdrowia ${ }^{17}$. W ustawie tej wskazuje się niejako na dwie kategorie danych - dane osobowe, ujęte w art. 4 ust. 3 pkt 1 oraz jednostkowe dane medyczne.

16 Ustawa z dnia 6 listopada 2008 roku o prawach pacjenta i Rzeczniku Praw Pacjenta. DzU z 2017 r. poz. 1318 t.j. z późn. zm.

17 Ustawa z dnia 28 kwietnia 2011 roku o systemie informacji w ochronie zdrowia. DzU z 2017 r. poz. 1845 t.j. z późn. zm. 
Dane osobowe są enumeratywnie wyliczone $\mathrm{i}$ ich zakres jest ograniczony treścią pkt 1: „Do danych osobowych zaliczamy: a) imię (imiona) i nazwisko, b) nazwisko rodowe, c) płeć, d) obywatelstwo, e) (uchylona) f) wykształcenie, g) numer PESEL, h) datę urodzenia, i) w przypadku osób, które nie mają nadanego numeru PESEL - numer paszportu albo innego dokumentu stwierdzającego tożsamość, j) adres miejsca zamieszkania i adres do korespondencji, k) adres miejsca pobytu na terytorium Rzeczypospolitej Polskiej, jeżeli dana osoba nie ma na terytorium Rzeczypospolitej Polskiej miejsca zamieszkania, 1) adres poczty elektronicznej, m) numer i rodzaj dokumentu potwierdzającego prawo do świadczeń opieki zdrowotnej finansowanych ze środków publicznych, n) stopień niepełnosprawności, o) rodzaj uprawnień oraz numer i termin ważności dokumentów potwierdzających uprawnienia do świadczeń opieki zdrowotnej określonego rodzaju oraz datę utraty tych uprawnień, p) numery identyfikacyjne i numery ewidencyjne nadawane usługobiorcom przez płatników lub usługodawców, r) datę zgonu, s) dane dotyczące zaświadczenia lekarskiego, o których mowa w art. 55 ust. 3 ustawy z dnia 25 czerwca 1999 roku o świadczeniach pieniężnych z ubezpieczenia społecznego w razie choroby i macierzyństwa (DzU z 2017 r. poz. 1368), t) przyczynę zgonu, u) informację o prawie do świadczeń opieki zdrowotnej finansowanych ze środków publicznych, v) numer identyfikacyjny płatnika, w) numer telefonu kontaktowego, $\mathrm{x}$ ) informację o sprzeciwie zawartym w centralnym rejestrze sprzeciwów na pobranie komórek, tkanek i narządów ze zwłok ludzkich, o którym mowa w art. 7 ust. 1 ustawy z dnia 1 lipca 2005 roku o pobieraniu, przechowywaniu i przeszczepianiu komórek, tkanek i narządów” (DzU z 2017 r. poz. 1000).

Za jednostkowe dane medyczne uważa się „dane osobowe oraz inne dane osób fizycznych dotyczące uprawnień do udzielonych, udzielanych i planowanych świadczeń opieki zdrowotnej, stanu zdrowia, a także inne dane przetwarzane $\mathrm{w}$ związku z planowanymi, udzielanymi i udzielonymi świadczeniami opieki zdrowotnej oraz profilaktyką zdrowotną i realizacją programów zdrowotnych". Interpretacja przepisów prowadzi do wniosku, że jednostkowe dane medyczne dzielą się na dane osobowe oraz dane inne niż osobowe. Jednakże przepisy te stoją $\mathrm{w}$ sprzeczności z ustawą o ochronie danych osobowych, ponieważ dane dotyczące osób fizycznych również stanowią dane osobowe. Jak wskazuje Mariusz Jagielski jedyne wyjście z sytuacji to zatem uznanie, że pojęcie „dane osobowe” na gruncie tej ustawy ma inne znaczenie niż na gruncie ustawy o ochronie danych osobowych (Jagielski, 2016, s. 6) i ogranicza się do danych identyfikujących pacjenta, a jednostkowe dane medyczne to zaś to samo, co dane osobowe w rozumieniu ustawy o ochronie danych osobowych. 
Prowadzi to do wniosku, że jednostkowe dane medyczne to wszystkie dane pacjenta - zarówno dane identyfikujące, jak i dane o osobie już identyfikowanej. Możliwe jest również, że taki podział ma na celu odróżnienie danych o stanie zdrowia od pozostałych danych osobowych. Należy podzielić w tym zakresie pogląd M. Jagielskiego, który wskazuje, że żadna z tych interpretacji nie jest konsekwentna w kontekście katalogu danych osobowych z art. 4 ust. 3 pkt 1, ponieważ np. dane o stopniu niepełnosprawności czy dane dotyczące zaświadczenia lekarskiego na temat zdrowia - są to informacje o osobie już zidentyfikowanej (Jagielski, 2016, s. 6).

Pomimo wielokrotnego posługiwania się, zarówno w ustawie o prawach pacjenta, jak i w ustawie o Rzeczniku Praw Pacjenta, a także w ustawie o systemie informacji w ochronie zdrowia, pojęciem „stanu zdrowia” czy „ochrony zdrowia”, żaden z tych aktów prawnych nie odpowiadał na pytanie, czym jest zdrowie i czym są dane dotyczące zdrowia.

Wydaje się więc, że odpowiedzi na te pytania należy szukać poza krajowym porządkiem. Próbę zdefiniowania czym jest zdrowie podjęła już w 1946 roku Światowa Organizacja Zdrowia, określając zdrowie jako „stan pełnego fizycznego, umysłowego i społecznego dobrostanu, a nie tylko całkowity brak choroby czy niepełnosprawności”"18.

Natomiast określenia, co rozumiem poprzez pojęcie „dane dotyczące zdrowia”, dokonano w ramach rekomendacji R(97)5 wskazując, że są to „wszelkie dane osobowe dotyczących stanu zdrowia danej osoby". Ponadto, pojęcie to odnosi się również do danych „mających oczywisty i ścisły związek ze zdrowiem oraz z danymi genetycznymi”. Definicja podana w rekomendacji nie wskazuje wprost, że do takich danych należy zaliczyć także informacje dotyczące nałogów, aczkolwiek stwierdzenie, że do danych dotyczących zdrowia zaliczają się „dane mające oczywisty i ścisły związek ze zdrowiem”, wydaje się nie stać w sprzeczności z zaliczeniem do nich także informacje o nałogach, które mają mieć przecież wpływ na stan zdrowia danej osoby. W doktrynie wskazuje się, że „pojęcie nałogu łączy się w praktyce z uzależnieniem [...] w pewnych wypadkach (choć nie zawsze) informacje o liczbie palonych papierosów lub też częstotliwości palenia mogą być uznane za dane wskazujące na nałóg”. Podobnie byłoby np. w przypadku informacji o rodzaju preferowanego alkoholu z jednej strony, która to informacja nie wskazuje na nałóg, a o częstotliwości jego spo-

18 Tłumaczenie własne. Tekst oryginalny: „Health is a state of complete physical, mental and social well-being and not merely the absence of disease or infirmity". Cytat pochodzi z Preambuły do Konstytucji Światowej Organizacji Zdrowia, Porozumienie zawarte przez Rządy reprezentowane na Międzynarodowej Konferencji Zdrowia i Protokół dotyczący Międzynarodowego Urzędu Higieny Publicznej, podpisane w Nowym Jorku dnia 22 lipca 1946 roku. 
żywania, która to informacja już nie może być w sposób tak oczywisty skategoryzowana (Barta, Lityński, 2015, s. 309).

\section{Dane dotyczące zdrowia w rozporządzeniu 2016/679 - analiza motywów i artykułów}

Rozporządzenie 2016/679, podtrzymując w tym zakresie terminologię z dyrektywy 95/46/WE, pozostaje przy pojęciu „dane dotyczące zdrowia”. RODO wprowadza ponadto definicję legalną danych dotyczących zdrowia wskazując, że są to „dane osobowe o zdrowiu fizycznym lub psychicznym osoby fizycznej - w tym o korzystaniu z usług opieki zdrowotnej - ujawniające informacje o stanie jej zdrowia”. Takie ujęcie danych dotyczących zdrowia rozumianych jako dane o zdrowiu fizycznym lub psychicznym jest zgodne $\mathrm{z}$ definicją zdrowia zaproponowaną przez Światową Organizację Zdrowia, w myśl której zdrowie to dobrostan fizyczny i psychiczny organizmu ${ }^{19}$.

Tak samo jak w dyrektywie 95/46/WE, w ogólnym rozporządzeniu o ochronie danych osobowych dane dotyczące zdrowia są zaliczane do szczególnych kategorii danych osobowych, których przetwarzanie jest co do zasady zakazane, jednakże istnieje wiele wyjątków od tego zakazu, ujętych w zamkniętym katalogu w art. 9 ust. 2. Nie ma wątpliwości, iż specyfika tych danych jako odnoszących się do sfery prywatności czy nawet intymności człowieka sprawia, iż konieczne jest zastosowanie szczególnych standardów ochrony w procesach przetwarzania tych informacji (Bielak-Jomaa, Lubasz, 2018, s. 278).

Jak wskazuje motyw 35 rozporządzenia „do danych osobowych dotyczących zdrowia należy zaliczyć wszystkie dane o stanie zdrowia osoby, której dane dotyczą, ujawniające informacje o przeszłym, obecnym lub przyszłym stanie fizycznego lub psychicznego zdrowia osoby, której dane dotyczą. Do danych takich należą informacje o danej osobie fizycznej zbierane podczas jej rejestracji do usług opieki zdrowotnej lub podczas świadczenia jej usług opieki zdrowotnej zgodnie z dyrektywą 2011/24/UE"20. Chodzi więc o informacje o obecnym, przeszłym lub prognozowanym stanie zdrowia. Są to więc zarówno dane podawane przez pacjenta podczas rejestracji np. w przychodni, ale także uzyskiwane podczas wywiadu lekarskiego czy uzyskane w wyniku dokonywanych badań. O ile nie budzi wątpliwości kwestia przeszłego czy też obecnego stanu zdrowia, o tyle rozważyć wypada, jakie dane mogą wskazywać na przy-

19 http://www.who.int/suggestions/faq/en/ (dostęp: 30.11.2017).

20 Dyrektywa Parlamentu Europejskiego i Rady 2011/24/UE z dnia 9 marca 2011 roku w sprawie stosowania praw pacjentów w transgranicznej opiece zdrowotnej. 
szły stan zdrowia. Można przypuszczać, że mogą to być w szczególności informacje na temat nieuleczalnych lub długotrwałych chorób i związanego z nimi leczenia, rokowań wynikających z obecnego stanu zdrowia, planowanych badań medycznych, zabiegów, operacji, wizyt lekarskich czy nawet terapii.

Ponadto, w motywie tym jest wymieniany katalog informacji, które zaliczają się do tej kategorii danych osobowych - numer, symbol lub oznaczenie przypisane danej osobie fizycznej w celu jednoznacznego zidentyfikowania tej osoby fizycznej do celów zdrowotnych; informacje pochodzące z badań laboratoryjnych lub lekarskich części ciała lub płynów ustrojowych, w tym danych genetycznych i próbek biologicznych; oraz wszelkie informacje, np. o: chorobie, niepełnosprawności, ryzyku choroby, historii medycznej, leczeniu klinicznym, stanie fizjologicznym lub biomedycznym osoby, której dane dotyczą, niezależnie od ich źródła, którym może być np. lekarz lub inny pracownik służby zdrowia, szpital, urządzenie medyczne lub badanie diagnostyczne in vitro. Katalog ten nie jest zamknięty - zawiera tylko przykładowe wyliczenie.

Także motyw 53 odnosi się pośrednio do danych dotyczących zdrowia poprzez wskazanie, że „szczególne kategorie danych osobowych zasługujące na większą ochronę powinny być przetwarzane do celów zdrowotnych wyłącznie w przypadkach, gdy jest to niezbędne do realizacji tych celów z korzyścią dla osób fizycznych i ogółu społeczeństwa”. Uwagę zwraca pojęcie „cele zdrowotne”. Porównując polskie tłumaczenie z angielskim widać rozbieżności, ponieważ w angielskiej wersji językowej rozporządzenia nie występuje sformułowanie „for health purposes”, ale „for health-related purposes”. Polskie tłumaczenie, nie do końca oddaje więc sens tego stwierdzenia, bo należałoby je raczej tłumaczyć jako „cele powiązane ze zdrowiem”. Ponadto, zgodnie ze Stownikiem Języka Polskiego PWN, słowo „zdrowotny” może oznaczać nie tylko „dotyczący stanu zdrowia”, ale również „korzystnie wpływający na zdrowie”. Należałoby więc uznać, że w tym przypadku chodzi raczej o to pierwsze znaczenie, ponieważ drugie zawęża rozumienie tego pojęcia i może wprowadzać w błąd co do zakresu znaczeniowego „celów zdrowotnych” jako takich celów, które służą tylko do polepszenia stanu zdrowia. Motyw 53 zawiera także katalog sytuacji, w których dochodzi do przetwarzania szczególnych kategorii danych osobowych (w tym danych dotyczących zdrowia) w celach zdrowotnych:

- zarządzanie usługami i systemami opieki zdrowotnej i zabezpieczenia społecznego, w tym przetwarzanie takich danych przez organy zarządcze i centralne krajowe organy ds. zdrowia do celów kontroli jakości;

- pozyskiwanie informacji zarządczych oraz ogólnego krajowego i lokalnego nadzoru nad systemem opieki zdrowotnej i zabezpieczenia społecznego; 
- zapewnianie ciągłości opieki zdrowotnej lub zabezpieczenia społecznego oraz transgranicznej opieki zdrowotnej;

- do celów bezpieczeństwa, monitorowania i ostrzegania zdrowotnego;

- do celów archiwalnych w interesie publicznym;

- do celów badań naukowych lub historycznych;

- do celów statystycznych, które mają podstawę w prawie Unii Europejskiej lub w prawie państwa członkowskiego i służą interesowi publicznemu;

- na potrzeby analiz prowadzonych $\mathrm{w}$ interesie publicznym $\mathrm{w}$ dziedzinie zdrowia publicznego.

Rozporządzenie wprowadza także szereg uregulowań odnoszących się do przetwarzania danych wrażliwych, np. wskazuje, że takie dane zgodnie z art. 22 ust. 4 nie mogą być przedmiotem decyzji podejmowanych w sposób zautomatyzowany, chyba że osoba wyraziła wyraźną zgodę lub przetwarzanie jest niezbędne ze względów związanych $\mathrm{z}$ ważnym interesem publicznym i istnieją właściwe środki ochrony praw, wolności i prawnie uzasadnionych interesów osoby, której dane dotyczą. Ponadto, art. 35 ust. 2 wskazuje, że obligatoryjnie należy przeprowadzić ocenę skutków dla ochrony danych danego rodzaju przetwarzania, w przypadku gdy wiąże się ono z przetwarzaniem na dużą skalę szczególnych kategorii danych osobowych, a w artykule 37 ust. 1 pkt c nakłada obowiązek wyznaczenia inspektora ochrony danych, gdy główna działalność administratora lub podmiotu przetwarzającego polega na przetwarzaniu na dużą skalę szczególnych kategorii danych osobowych.

\section{Wyraźna a nie pisemna zgoda na przetwarzanie danych wrażliwych}

Przetwarzanie szczególnych kategorii danych osobowych jest dopuszczalne wyłącznie w okolicznościach określonych w art. 9 ust 2 RODO. W porównaniu z regulacją zawartą w dyrektywie 95/46/WE katalog tych przesłanek jest w zasadzie zbliżony, aczkolwiek w rozporządzeniu 2016/679 wprowadzono dwa nowe wyjątki od zakazu przetwarzania danych wrażliwych: interes publiczny w dziedzinie zdrowia publicznego oraz realizację celów archiwalnych w interesie publicznym, celów badań naukowych lub historycznych lub celów statystycznych. Niektóre z pozostałych przesłanek zostały natomiast nieco inaczej ujęte (zob. m.in. Jarguz, 2017, s. 95).

Podstawową przesłanką uchylającą zakaz przetwarzania danych sensytywnych jest zgoda osoby, której dane dotyczą. Głównym elementem odróżniającym jednak oświadczenie o wyrażeniu zgody na przetwarzanie danych z art. 27 
ust. 2 pkt 1 od oświadczenia z art. 23 ust. 1 pkt 1 ustawy o ochronie danych osobowych jest wymóg złożenia takiego oświadczenia na piśmie. Wartym podkreślenia jest, że dyrektywa 95/46/WE nie zawierała wymogu pisemnej zgody - polski ustawodawca zdecydował się jednak dodać ten wymóg implementując dyrektywę. W literaturze (Barta, Fajgielski, Markiewicz, 2015, s. 490-491; Drozd, 2008, s. 171) panował pogląd, że zgoda na przetwarzanie wrażliwych danych osobowych udzielona $\mathrm{w}$ formie innej niż pisemna jest nieskuteczna, a przepisy Komisji o formie czynności prawnych nie znajdują w tym zakresie zastosowania. Dochowanie więc formy pisemnej było warunkiem skuteczności takiego oświadczenia (Barta, Litwiński, 2015, s. 210).

Takie sformułowanie zgody stanowi istotne novum, ponieważ określenia wymaga, kiedy zgodę można uznać za wyraźną. Już w trakcie prac nad dyrektywą 95/46/WE rozważano, czy do zgody dotyczącej przetwarzania danych wrażliwych należy dodać wymóg pisemności jako dodatkowy w stosunku do tego, że zgoda powinna być wyraźna ${ }^{21}$. Ostatecznie jednak w dyrektywie odstąpiono od wyrażania zgody w formie pisemnej. W uzasadnieniu Rady22 nie podano konkretnych wyjaśnień wprowadzonych zmian. Na stronie 4 stwierdzono jednak: „wprowadzono [...] pewne zmiany w celu [...] uzyskania pewnej elastyczności, która gwarantuje równoważną ochronę [...], ale nie skutkuje obniżeniem poziomu ochrony; umożliwiają one efektywne i pozbawione biurokratycznych obciążeń stosowanie ogólnych zasad, uwzględniając znaczną różnorodność sposobów [...] przetwarzania danych"23.

Jak wskazano w Opinii Grupy Roboczej dotyczącej zgody z 2011 roku „zgoda wyraźna ma miejsce we wszystkich sytuacjach, gdy osobie fizycznej przedstawia się propozycję wyrażenia przyzwolenia (lub nie) na konkretny sposób wykorzystania lub ujawnienia jej danych osobowych, a osoba ta aktywnie (ustnie lub pisemnie) odpowiada na zadane pytanie"24.

21 W art. 17 wniosku Komisji dotyczącym dyrektywy w sprawie ochrony osób fizycznych w zakresie przetwarzania danych osobowych, COM(90)314 wersja ostateczna, SYN 287 i 288, Bruksela, 13 września 1990 roku dotyczącym danych szczególnie chronionych znalazł się wymóg, aby zgoda była „wyraźna i pisemna”. Natomiast w zmienionym wniosku Komisji dotyczący dyrektywy Rady w sprawie ochrony osób fizycznych w zakresie przetwarzania danych osobowych i swobodnego przepływu tych danych, COM(92)422 wersja ostateczna - SYN 287, Bruksela, 15 października 1992 roku w przypadku danych szczególnie chronionych zachowano wymóg zgody „pisemnej”.

22 Wspólne stanowisko Rady w sprawie wniosku dotyczącego dyrektywy Parlamentu i Rady w sprawie ochrony osób fizycznych w zakresie przetwarzania danych osobowych i swobodnego przepływu tych danych, (00/287) COD, przyjęte 15 marca 1995 roku, s. 4.

23 Opinia 15/2011 w sprawie definicji zgody, http://ec.europa.eu/justice/data-protection/article-29/ documentation/opinion-recommendation/files/2011/wp187_pl.pdf, s. 5 i 6 (dostęp: 29.11.2017).

24 Ibidem, s. 27. 
Jak wskazano w odniesieniu do usług on-line, zaznaczenie check-boxa „na formularzu po otrzymaniu odpowiednich informacji stanowi wyraźną, jednoznaczną zgodę, gdyż działanie polegające na zaznaczeniu pola wyboru jest wystarczająco jasne, by nie pozostawiać wątpliwości co do woli uczestnictwa osoby fizycznej w programie lojalnościowym". Takie rozumienie wyraźnej zgody znacząco zmienia sytuację $\mathrm{w}$ odniesieniu do przetwarzania danych osobowych wrażliwych, w tym danych dotyczących zdrowia w środowisku internetowym, dając szansę m.in. na efektywny rozwój usług medycznych świadczonych w formie telemedycyny.

Jeśli szczególne kategorie danych osobowych, w tym dane dotyczące zdrowia, są przetwarzane na podstawie zgody, powinna ona być nie tylko wyraźna, ale przede wszystkim spełniać wszystkie wymogi, o których mowa w definicji zgody z art. 4 pkt 11 i art. 7, który wskazuje na warunki jej wyrażenia, tj.:

- powinna być wyrażona przez osobę, której dane dotyczą;

- stanowi dobrowolne, konkretne, świadome i jednoznaczne okazanie woli, którym może być oświadczenie woli lub wyraźne działanie potwierdzające;

- powinna zawierać przyzwolenie na przetwarzanie danych osobowych ${ }^{25}$;

- nie może być od niej uzależnione wykonanie umowy, w tym świadczenie usługi, jeśli przetwarzanie danych osobowych nie jest niezbędne do wykonania tej umowy;

- oświadczenie o zgodzie powinno zawierać informację, że osoba ma prawo w dowolnym momencie wycofać zgodę co nie wpływa na zgodność z prawem przetwarzania, którego dokonano na jej podstawie przed wycofaniem;

- oświadczenie o zgodzie powinno być przedstawione w sposób pozwalający wyraźnie odróżnić je od pozostałych kwestii, w zrozumiałej i łatwo dostępnej formie, jasnym i prostym językiem;

- administrator powinien móc wykazać, że zgoda została wyrażona - wyrażenie zgody powinno zostać utrwalone np. w formie nagrania, e-maila, na piśmie itp.

Rozporządzenie w art. 8 odnosi się także do zgody wyrażonej przez dziecko, w przypadku usług społeczeństwa informacyjnego oferowanych bezpośrednio dziecku wskazując, że „Jeżeli zastosowanie ma art. 6 ust. 1 lit. a, w przypadku usług społeczeństwa informacyjnego oferowanych bezpośrednio dziecku, zgodne z prawem jest przetwarzanie danych osobowych dziecka, które ukończyło 16 lat. Jeżeli dziecko nie ukończyło 16 lat, takie przetwarzanie jest zgodne

25 Wydaje się więc, że samo „Wyrażam zgodę” nie spełnia tego warunku. Tak samo „Wyrażam zgodę na nieprzetwarzanie moich danych osobowych" również go nie spełnia, gdyż nie stanowi działania potwierdzającego, lecz działanie zaprzeczające. 
z prawem wyłącznie w przypadkach, gdy zgodę wyraziła lub zaaprobowała ją osoba sprawująca władzę rodzicielską lub opiekę nad dzieckiem oraz wyłącznie w zakresie wyrażonej zgody". Przepis ten budzi wiele wątpliwości interpretacyjnych (Bielak-Jomaa, Lubasz, 2018, s. 427-436), w dużym stopniu spowodowanych brakiem m.in. określenia mechanizmu wyrażania lub aprobowania zgody dziecka, regulacji sposobów weryfikacji tożsamości udzielających zgodę, uregulowania granicy wieku, poniżej której dziecko zgody w ogóle wyrazić nie może 26 .

Z perspektywy niniejszych rozważań istotne jest jednak, czy dziecko, które ukończyło 16 rok życia ${ }^{27}$ może wyrazić zgodę na przetwarzanie danych dotyczących zdrowia, w przypadku korzystania z usług społeczeństwa informacyjnego oferowanych bezpośrednio dziecku. Na tak postawione pytanie należy udzielić odpowiedzi negatywnej, ponieważ art. 8 wskazuje, że podstawą zgody dziecka nie jest zgoda $\mathrm{z}$ art. 9 ust. 2 pkt $b$, a zgoda $\mathrm{z}$ art. 6 ust 1 pkt a, która nie stanowi przesłanki legalizującej przetwarzanie szczególnych kategorii danych.

\section{Podsumowanie}

Ogólne rozporządzenie o ochronie danych osobowych jest stosowane od 25 maja 2018 roku. Celem regulacji było przede wszystkim zapewnienie wysokiego i spójnego stopnia ochrony osób fizycznych oraz usunięcie przeszkód w przepływie danych osobowych w Unii Europejskiej. Należało więc zapewnić równorzędny we wszystkich państwach członkowskich stopień ochrony praw i wolności osób fizycznych w związku z przetwarzaniem takich danych.

Rozporządzenie tak samo jak dyrektywa wyróżniało szczególne kategorie danych osobowych i pozostałe dane, nazywane danymi zwykłymi. Jak wskazuje motyw 51 szczególne kategorie danych ,z racji swego charakteru są szczególnie wrażliwe w świetle podstawowych praw i wolności i dlatego wymagają szczególnej ochrony, gdyż kontekst ich przetwarzania może powodować poważne ryzyko dla podstawowych praw i wolności”. Do takich danych zalicza się dane dotyczące zdrowia, których definicja została ujęta w art. 4 pkt 15 rozporządzenia. Rozporządzenie posługuje się nazwą funkcjonującą już w dyrektywie 95/46/WE, podczas gdy do tej pory w polskiej ustawie, funkcjonowało pojęcie

26 Por. Uzasadnienie do projektu ustawy o ochronie danych osobowych, s. 7-11, https://legislacja. rcl.gov.pl/docs//2/12302950/12457664/12457665/dokument308360.pdf (dostęp: 26.11.2017).

27 W Uzasadnieniu do projektu ustawy o ochronie danych osobowych projektodawca proponuje obniżenie granicy wieku do 13. roku życia, wykorzystując kompetencję przyznaną państwom członkowskim w myśl art. 8 ust. 1, s. 7-11, https://legislacja.rcl.gov.pl/docs//2/12302950/1245 7664/12457665/dokument308360.pdf (dostęp: 26.11.2017). 
dane o stanie zdrowia i nie było jasne czy zakres znaczeniowy tych pojęć jest tożsamy.

Ponadto, rozporządzenie wprowadza nowe wymogi dotyczące zgody, zastępując zgodę pisemną zgodą wyraźną - co w dużej mierze racjonalizuje podejście dotyczące zgody, gdyż współczesne metody uwierzytelniania, np. profil zaufany ${ }^{28}$ czy podpis elektroniczny ${ }^{29}$, zapewniają gwarancje bezpieczeństwa danych i uwierzytelniają osobę, której dane dotyczą przynajmniej w stopniu, który do tej pory gwarantował własnoręcznie złożony podpis tej osoby.

Rozporządzenie wprowadza także zmiany w zakresie zgody dziecka, jednak w wielu kwestiach pozostawia wiele pytań o sposoby wdrożenia jego postanowień, które mogą prowadzić nie tylko do zróżnicowania podejścia, lecz także do zróżnicowania stopnia ochrony między krajami członkowskim, podczas gdy jednym z celów było ujednolicenie ochrony w ramach krajów członkowskich. Niewątpliwie jednak w zakresie usług społeczeństwa informacyjnego oferowanych bezpośrednio, które miałyby obejmować dane wrażliwe, nie ma możliwości skutecznego wyrażenia zgody przez dziecko, które ukończyło 16 lat, gdyż sytuacja ta obejmuje wyłącznie zgodę na przetwarzanie danych zwykłych $\mathrm{z}$ art. 6 ust. 1 pkt a.

Niewątpliwie regulacje obligujące do zwiększenia ochrony m.in. przez obowiązek powołania inspektora ochrony danych, dokonania oceny skutków dla ochrony danych osobowych czy elastyczne regulacje poszczególnych przepisów RODO, np. w zakresie bezpieczeństwa przetwarzania wskazują, że ustawodawca unijny widział potrzebę uwzględnienia stopnia ochrony danych także w zależności od kategorii przetwarzanych danych osobowych.

Administratorzy przetwarzający dane dotyczące zdrowia powinni mieć podwyższone środki do ich ochrony, ponieważ przetwarzanie szczególnych kategorii danych, nawet $\mathrm{z}$ uwzględnieniem złagodzonych warunków dotyczących zgody, jest nadal możliwe tylko w ściśle określonych sytuacjach, a z uwagi na podejście oparte na ryzyku, to na administratorze będzie spoczywał obowiązek zabezpieczenia tych danych w sposób adekwatny do poziomu ryzyka ich naruszenia.

28 Ustawa z dnia 17 lutego 2005 roku o informatyzacji działalności podmiotów realizujących zadania publiczne. DzU z 2005 r., nr 64 poz. 565 z późn. zm.

29 Ustawa z dnia 5 września 2016 roku o usługach zaufania oraz identyfikacji elektronicznej. DzU z 2016 r., poz. 1579. 


\section{Bibliografia}

Barta, J., Fajgielski, P. i Markiewicz R. (2015). Ochrona danych osobowych. Komentarz. Warszawa: Wydawnictwo Wolters Kluwer bussiness.

Barta, P., Litwiński, P. (2015). Ustawa o ochronie danych osobowych. Komentarz. Warszawa: Wydawnictwo C.H. Beck.

Bielak-Jomaa, E., Lubasz, D. (2018). RODO. Ogólne rozporządzenie o ochronie danych osobowych. Komentarz. Warszawa: Wolters Kluwer Polska.

Drozd, A. (2008). Ustawa o ochronie danych osobowych. Komentarz. Wzory pism i przepisy. Warszawa: Wydawnictwo Prawnicze LexisNexis.

Dyrektywa 95/46/WE Parlamentu Europejskiego i Rady z dnia 24 października 1995 roku w sprawie ochrony osób fizycznych w zakresie przetwarzania danych osobowych oraz swobodnego przepływu tych danych. Dz.Urz. WE, z 23 listopada 1995 r., L 281.

Dyrektywa Parlamentu Europejskiego i Rady 2011/24/UE z dnia 9 marca 2011 roku w sprawie stosowania praw pacjentów w transgranicznej opiece zdrowotnej. Dz.Urz. UE z 2011 r., L88/45.

http://www.who.int/suggestions/faq/en/ (dostęp: 30.11.2017).

Jagielski, M. (2016). Pojęcie danych medycznych i zasady ich ochrony. W: Ochrona danych osobowych medycznych. Warszawa: Wydawnictwo C.H. Beck.

Jarguz, J. (2017). Zewnętrzna obsługa: zewnętrzna obsługa kadrowo-płacowa, zewnętrzna obsługa w zakresie badań profilaktycznych, prywatna opieka zdrowotna pracowników. W:

D. Dörre-Kolasa (red.). Ochrona danych osobowych pracowników w świetle rozporzadzenia Parlamentu Europejskiego i Rady. Warszawa: Wydawnictwo C.H. Beck.

Konwencja nr 108 Rady Europy o ochronie osób w związku z automatycznym przetwarzaniem danych osobowych, sporządzona w Strasburgu dnia 28 stycznia 1981 roku. DzU z 2003 r., nr 3, poz. 25.

Krasińska, M. (2016). Przetwarzanie danych osobowych w dokumentacji medycznej. W: Ochrona danych osobowych medycznych. Warszawa: Wydawnictwo C.H. Beck.

Kulesza, E. (2000). Ochrona danych o stanie zdrowia w świetle ustawodawstwa europejskiego i polskiej ustawy o ochronie danych osobowych. Prawo i Medycyna (5).

Ocena skutków regulacji - Projekt ustawy o ochronie danych osobowych, s. 3, https:// legislacja.rcl.gov.pl/docs//2/12302950/12457664/12457665/dokument308359.pdf (dostęp: 24.11.2017).

Opinia 15/2011 w sprawie definicji zgody, http://ec.europa.eu/justice/data-protection/article-29/ documentation/opinion-recommendation/files/2011/wp187_pl.pdf (dostęp: 29.11.2017).

Preambuła do Konstytucji Światowej Organizacji Zdrowia, Porozumienie zawarte przez Rządy reprezentowane na Międzynarodowej Konferencji Zdrowia i Protokół dotyczący Międzynarodowego Urzędu Higieny Publicznej, podpisane w Nowym Jorku dnia 22 lipca 1946 roku. DzU z 1948 r., nr 61 poz. 477.

Projekt ustawy - Przepisy wprowadzające ustawę o ochronie danych osobowych, https:// legislacja.rcl.gov.pl/docs//2/12302951/12457706/12457707/dokument308373.pdf (dostęp: 22.11.2017).

Projekt ustawy o ochronie danych osobowych, https://legislacja.rcl.gov.pl/docs//2/12302950/ 12457664/12457665/dokument308361.pdf (dostęp: 22.11.2017).

Recommendation No.R (97) 5 of the Committee of Ministers to Member States on the protection of medical data (Adopted by the Committee of Ministers on 13 February 1997 at the 584th meeting of the Ministers' Deputies), https://www.google.pl/url?sa=t 
$\& r c t=j \& q=\& e s r c=s \&$ source $=$ web $\& c d=1 \& c a d=$ rja $\&$ uact $=8 \& v e d=0$ ahUKEwjq5oOO 0 eHXAhWJIOwKHRqnDaMQFggqMAA\&url=https\%3A\%2F\%2Frm.coe.int $\% 2 F C o E R$ MPublicCommonSearchServices\%2FDisplayDCTMContent\%3FdocumentId\%3D09000 016806af967\&usg=AOvVaw2acyV-MKt3tPhMKpE7yAMD (dostęp: 26.11.2017).

Rozporządzenie Parlamentu Europejskiego i Rady (UE) 2016/679 z dnia 27 kwietnia 2016 roku w sprawie ochrony osób fizycznych w związku z przetwarzaniem danych osobowych i w sprawie swobodnego przepływu takich danych oraz uchylenia dyrektywy 95/46/WE.

Sibiga, G. (2003). Postępowanie w sprawach ochrony danych osobowych. Warszawa: Dom Wydawniczy ABC.

Słownik języka polskiego PWN. https://sjp.pwn.pl/szukaj/zdrowotny.html (dostęp: 28.12.2017). Ustawa $\mathrm{z}$ dnia 17 lutego 2005 r. o informatyzacji działalności podmiotów realizujących zadania publiczne. DzU z 2005 r., nr 64 poz. 565 z późn. zm.

Ustawa z dnia 28 kwietnia 2011 r. o systemie informacji w ochronie zdrowia. DzU z 2017 r., poz. 1845 t.j. z późn. zm.).

Ustawa z dnia 29 sierpnia 1997 roku o ochronie danych osobowych. DzU z 1997 r., nr 133 poz. 883.

Ustawa z dnia 5 września 2016 r. o usługach zaufania oraz identyfikacji elektronicznej. DzU z 2016 r. poz. 1579).

Ustawa z dnia 6 listopada 2008 r. o prawach pacjenta i Rzeczniku Praw Pacjenta. DzU z 2017 r. poz. 1318 t.j. z późn. zm.

Uzasadnienie do projektu ustawy o ochronie danych osobowych, https://legislacja.rcl.gov.pl/ docs//2/12302950/12457664/12457665/dokument308360.pdf (dostęp: 26.11.2017).

Wąsik, D. (2015). Komentarz do art. 2 ustawy o systemie informacji w ochronie zdrowia.

W: D. Wąsik. Ustawa o systemie informacji w ochronie zdrowia. Komentarz. Warszawa: Wydawnictwo Wolters Kluwer. 